\title{
Entrepreneurship perception among vulnerable population groups in Romania
}

\author{
Carmen PĂUNESCU \\ Bucharest University of Economic Studies, UNESCO Department for Business Administration, \\ Bucharest, Romania \\ carmen.paunescu@ase.ro
}

\begin{abstract}
Alexandra Ioana PASCU
Bucharest University of Economic Studies, Doctoral School for Business Administration, Bucharest, Romania alex.ioana.pascu@gmail.com

Adina FILCULESCU

Bucharest University of Economic Studies, Doctoral School for Business Administration, Bucharest, Romania adinafilculescu@gmail.com

\section{Raluca BADEA}

Bucharest University of Economic Studies, Doctoral School for Business Administration, Bucharest, Romania badraluca@gmail.com
\end{abstract}

\begin{abstract}
This paper aims to explore the entrepreneurship perception among diverse populations in Romania typically seen as vulnerable. It also aims to provide support regarding how the concept might be useful in considering and designing alternative policy interventions. The vulnerable population groups studied in the paper differ by age (seniors), gender (females), income (low income population) and residence (rural community). The paper attempts to answer three research questions: (1) how attitudes towards entrepreneurship differ among vulnerable population groups; (2) how intention of starting a business varies among studied population; and (3) what is the likelihood and desirability of studied population to consider entrepreneurship as a career choice. The data analysed in the paper are extracted from the Amway Global Entrepreneurship Report (AGER) developed for Romania, for the period 2014-2016. Analysis is conducted by taken into consideration the following dimensions of the "entrepreneurship perception": attitude towards entrepreneurship, intention of starting a business, entrepreneurship as a career choice, and likelihood of self-employment. The paper aims to contribute to advancing research on the less addressed and less understood entrepreneurship perception among vulnerable populations. In the paper we make recommendations for governmental institutions that are meant to contribute to designing policy interventions that will nurture entrepreneurship spirit in Romania.
\end{abstract}

Keywords: entrepreneurship attitudes, vulnerable population, seniors, females, low income population, rural community, AGER.

\section{Introduction}

Nowadays, entrepreneurship has a key role in ensuring a nation's innovativeness and competitiveness, contributing to employment and social development which subsequently 
lead to promoting economic growth and social sustainability. A valuable resource for entrepreneurship could be represented by those people who do not have necessary capabilities to find a job for themselves or have limited access to resources and are disadvantaged by their nature. So far, very few empirical analysis have been conducted with regards to entrepreneurship perception among disadvantaged people who are regarded by society as being vulnerable populations. The current paper attempts to fill in this gap by addressing this issue for Romania.

Thus, the paper aims to explore the perception about entrepreneurship among four groups of population in Romania typically seen as vulnerable, namely seniors, females, low income people and rural population. Also, it attempts to draw some recommendations for policy makers to be considered in designing policy interventions meant to enhance entrepreneurial spirit among vulnerable populations in Romania and improve their life quality. The paper starts with a brief review of the literature. Then it explains the methodology used to assess the perception of entrepreneurship among vulnerable populations. Finally, analysis is conducted on selected data and conclusions are drawn based on results.

\section{Literature review}

\section{Insights into entrepreneurship among vulnerable populations}

Vulnerability results from the interaction between limited resources available to individuals or communities and the life challenges and opportunities they face (Goh, 2015; Shabunova et al., 2016). Limitations in resources lead more likely to poverty, social exclusion and lack of social support, working in a hazardous environment or not working. Also, vulnerability results from the complex interactions of multiple other factors like personal incapacities, poor education, family deficiencies, inadequacy of interpersonal relationships, and degraded working and living environments. These interactions usually increase over the life course of an individual.

In the literature vulnerable population groups are usually treated similarly to groups of population in need, susceptible to harm, who lack skills and capabilities to access their neighbourhood resources, such as schools, jobs or housing (Berthe et al., 2013). On the contrary, vulnerable populations should be regarded as valuable resource for entrepreneurship. People aged 55 to 75, for example, are perceived as being vulnerable as they might be missing job opportunities and promotion, usually have a low income level, face more frequently health issues, and feel too old to address new challenges. On the other hand, seniors often have the skills, financial resources and time available to start a business and contribute to economic activity (Botham \& Graves, 2009). Engaging seniors in both business creation and in supporting new and existing entrepreneurs would maximize the quality of their working life, nurture intergenerational learning and ensure knowledge transfer (OECD, 2012). Even if the overall interest of senior population regarding intention of starting a business seems to declining (Păunescu \& Blid, 2017), there are various tools which can be used to increase the willingness and desirability of senior population to start up a business and become self-employed.

Females are also perceived as being disadvantaged as they are less represented among business managers and entrepreneurs than their male counterparts and this signals that there is a market failure which leads to discriminatory practices that need to be

DOI: 10.2478/picbe-2018-0064, pp. 718-727, ISSN 2558-9652| Proceedings of the $12^{\text {th }}$ International Conference on Business 
investigated and addressed. Anwar and Rashid (2011) brings extensive arguments on the ways in which entrepreneurship can be used to empower women living in developing countries. Also, encouraging female entrepreneurship will help women overcome many of the problems they face, including housing and adequate income, lack of security and isolation, self-achievement (Goudarzi et al., 2016; Purdue, 2017). Unlike the majority of men, women see entrepreneurship as a means to balance work responsibilities and earn an income with domestic and family duties, as business ownership is associated with higher flexibility and the possibility of combining work with childcare (McGowan et al., 2012). Thus, there is yet untapped potential for women to become noticeable contributors for achieving economic growth and development.

The level of income and accumulated assets are also regarded as determinant factors in defining the social status of an individual and the well-being of his/her community. A disadvantaged social status embraces many looks: poverty, limited opportunities for employment and education, lack of access to social and community networks and activities, inability to plan one's own life (Shabunova et al., 2016). Therefore, low income people are also regarded as being vulnerable population in their community.

Rural communities also represent another group of vulnerable population as they have quite rare paid work opportunities in their regions and limited access to available resources for them. Rural entrepreneurship development and employment generation are fundamental to enhancing local or regional level progress and transformation (Salleh \& Sidek, 2011). Achieving gainful employment in rural communities contributes immensely to the realisation of the potential of people living in remote communities (Kolawole \& Ajila, 2015). Entrepreneurship in the rural context becomes extremely important because it assists to complement scarce resources and create new opportunities for rural development base by establishing a relationship between rural actors with other actors (Hukampal \& Bhowmick, 2016).

Therefore, potential of an individual to become entrepreneur depends on the existence of a favourable micro-social and cultural environment which may influence his entrepreneurial predisposition and perception and will lead towards understanding the entrepreneurial activities, with both success and failure.

\section{Methodology}

The paper aims to explore the perception about self-employment of four groups of vulnerable population in Romania: females, seniors, low income people and rural community population. They differ by age, gender, income and size of community. In order to reach its goal, the main specific objectives set in the paper are as follows: 1) analysing how attitudes towards entrepreneurship differ among vulnerable population groups; 2) understanding how interest in starting a business varies among the population groups studied, for population who manifest a positive vs. negative attitude towards entrepreneurship; and 3) analysing the likelihood and desirability of the population studied to consider entrepreneurship as a career choice.

To achieve its objectives, the current research analyses the data available from the Amway Global Entrepreneurship Reports (AGER) prepared for Romania, for the period 2014-2016. For five years now, Amway, in partnerships with academic partners and a world leading market research company from Germany (Gesellschaft fuer

DOI: 10.2478/picbe-2018-0064, pp. 718-727, ISSN 2558-9652| Proceedings of the $12^{\text {th }}$ International Conference on Business Excellence 2018 
Konsumforschung), develops a ground breaking research on self-employment around the world. Annually, they carry out a survey in April-May, through face-to-face or telephone interviews, by using a fully structured questionnaire, with questions asked in a given order and wording. In 2016 the survey spanned 45 markets and more than 50,000 people. The procedures used to select participants from the whole universe of each market population ensure a representative sample. In Romania the total number of valid questionnaires interpreted in the reports was 1,052 in 2014, 1,084 in 2015 and 1,023 questionnaires in 2016.

For the purpose of the current research the following population groups have been selected for analysis (Appendix 1): seniors from the age group 60+ years (2014: $n=254$, 2015: $n=288$ and 2016: $n=271$ ), females (2014: $n=547,2015: n=562$ and 2016: $n=531$ ), people belonging to households with a monthly net income up to 1000 RON (2014: $n=181$, 2015: $n=192$ and 2016: $n=145)$ and people from rural communities (2014: $n=444,2015$ : $n=499$ and 2016: $n=471$ ). In the paper we interpret the entrepreneurship perception of each one of these population groups by taking into consideration the following dimensions: attitude towards entrepreneurship, interest in starting a business, and desirability to embrace an entrepreneurship career. Attitude measures perception of respondents regarding challenges and opportunities brought about by starting a business and becoming self-employed. Interest measures perceived intention of starting a business. Desirability assesses perception about starting a business as a desirable career opportunity. For comparison purpose, we use as reference basis the entrepreneurship perception of selfemployed population (2014: $n=41,2015: n=52$ and 2016: $n=33$ ), measured against the same dimensions.

All the population groups studied cope with specific problems and vulnerabilities in terms of entrepreneurship, and represent vulnerable population groups which require policy interventions.

Our research assumes the following: (1) The attitude towards entrepreneurship among vulnerable populations in Romania remains mostly reserved and, on average, positive; (2) Intention of starting a business varies significantly among the vulnerable populations studied, is rather low and the trend line is decreasing; and (3) Desirability of self-employment among vulnerable population in Romania is relatively low and displays a decreasing trend line. To test the research assumptions we analysed time series and average weights for each one of the variables measured in the analysis.

\section{Results and discussions}

\section{Attitude towards entrepreneurship}

A country's attitudes towards entrepreneurship influence significantly the propensity of individuals to become entrepreneurs. Positive attitudes towards entrepreneurship are found to correlate with high levels of entrepreneurship (OECD, 2012).

For our populations studied, the positive attitude towards entrepreneurship is visibly decreasing for people of age $60+$, from $54.1 \%$ in 2014 to $38.0 \%$ in 2016 , with a decreasing rate of $29.7 \%$, and consequently their negative attitude is increasing from $32.2 \%$ in 2014 to $43.5 \%$ in 2016, with an even faster increasing rate of $35.1 \%$ (Figure 1). The positive attitude towards entrepreneurship of females is noticeably decreasing from $73.2 \%$ in 2014 to $50.6 \%$ in 2016 , with a decreasing rate of $30.8 \%$, and consequently their negative

DOI: $10.2478 /$ picbe-2018-0064, pp. 718-727, ISSN 2558-9652| Proceedings of the $12^{\text {th }}$ International Conference on Business 
attitude is increasing from $19.5 \%$ in 2014 to $35.5 \%$ in 2016, with a much faster increasing rate of $82.0 \%$. Furthermore, people who earn a monthly net income of up to 1000 RON per household display a tremendously decreasing trend line regarding their positive attitude towards entrepreneurship, from $60.2 \%$ in 2014 to $38.8 \%$ in 2016 (but a slight increase relative to 2015), which represents a decrease of $35.5 \%$. Consequently, their negative attitude towards entrepreneurship is visibly increasing from $24.5 \%$ in 2014 to $42.7 \%$ in 2016 , with a very fast increasing rate of $74.2 \%$. For people from rural communities the overall attitude towards entrepreneurship remain mainly positive, but the trend line is visibly decreasing from $72.7 \%$ in 2014 to $51.9 \%$ in 2016, with a decreasing rate of $28.6 \%$, and consequently their negative attitude towards entrepreneurship is increasing from $18.4 \%$ in 2014 to $35.5 \%$ in 2016 , with much faster increasing rate of $92.9 \%$.

On the other hand, people who are self-employed display an overall positive attitude towards entrepreneurship which decreased from 2014 (91.0\%) to 2015 (71.1\%), but slightly increased from 2015 up to 2016 (74.1\%). Their negative attitude towards entrepreneurship increased as well from $6.9 \%$ in 2014 to $24.4 \%$ in 2015 , and a slight decrease in $2016(22.7 \%)$.

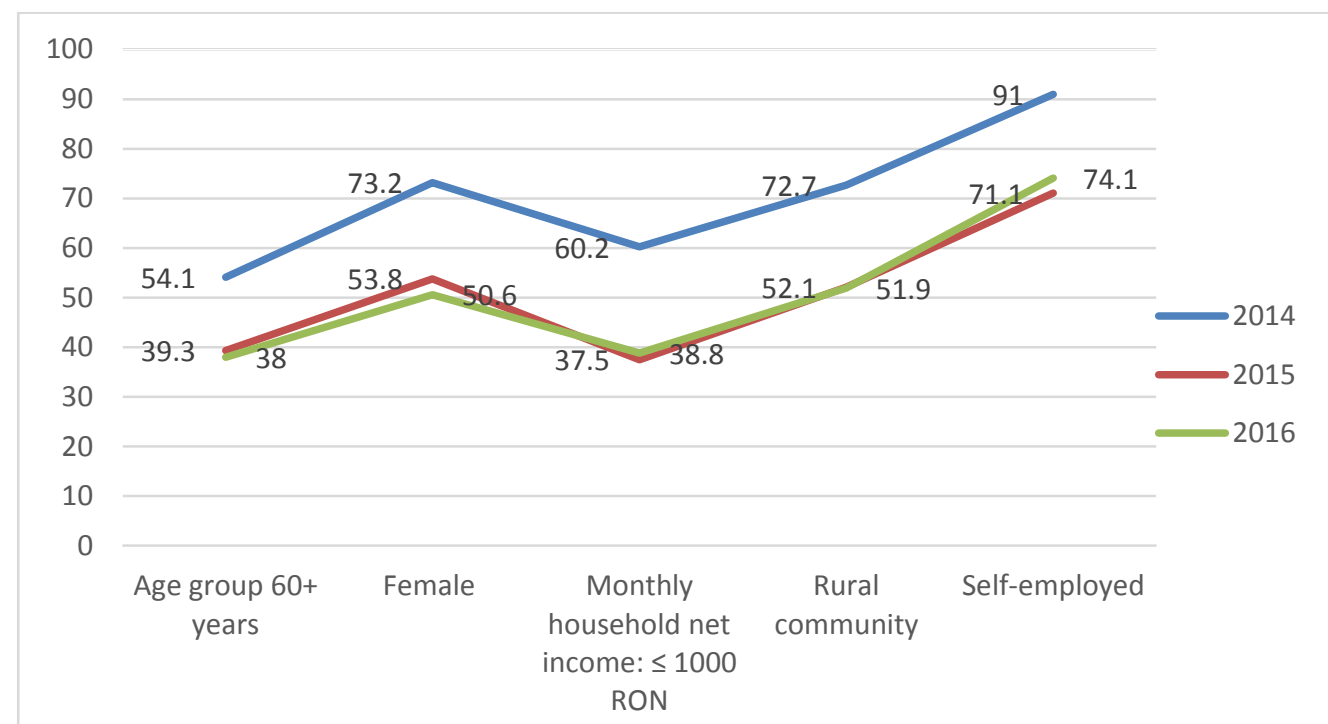

Figure 1. Trend lines of entrepreneurship positive attitude among sample populations (\%) Source: Authors' own research. Processed based on AGER 2014 $\div 2016$ data.

\section{Intention of starting a business}

When it comes to perceived intention of creating a new business, a smaller and smaller number of people of age $60+$, who have a positive attitude towards entrepreneurship, can imagine starting their own business (a decrease of $72.6 \%$, from $8.4 \%$ in 2014 to $2.3 \%$ in 2016) (Figure 2). However, in 2016 there are $2.0 \%$ of seniors with negative attitude towards entrepreneurship willing to start their own business, representing also a decreasing trend line relative to 2014 (3.1\%). Also, in 2016, only $12.5 \%$ females who have a positive attitude towards entrepreneurship in comparison with $28.0 \%$ in 2014 (a decrease of 55.3\%) can imagine starting their own business. However, in 2016 a larger number of females with negative attitude towards entrepreneurship are willing to start their own 
business, representing an increasing rate of $58.6 \%$ relative to 2014 , slightly faster than the previous rate. Furthermore, only $5.1 \%$ of people with a monthly net income of up to 1000 RON, who have a positive attitude towards entrepreneurship, imagine starting their own business in 2016 and the trend line is decreasing since 2014, with a decrease of $61.1 \%$. However, in 2016 a slightly larger number of those people who display a negative attitude towards entrepreneurship are willing to start their own business, representing an increasing rate of $54.5 \%$ relative to 2014 , slower than the previous rate. The willingness of people from rural areas who have a positive attitude towards entrepreneurship to start their own business is still low (but higher than the one for seniors) and displays a decreasing trend line (a decrease of $42.6 \%$, from $23.9 \%$ in 2014 to $13.7 \%$ in 2016). However, in 2016 a larger number of people from rural communities with negative attitude towards entrepreneurship show willingness to start their own business, representing an increasing rate of $22.6 \%$ relative to 2014 (from $3.1 \%$ to $3.8 \%$ ).

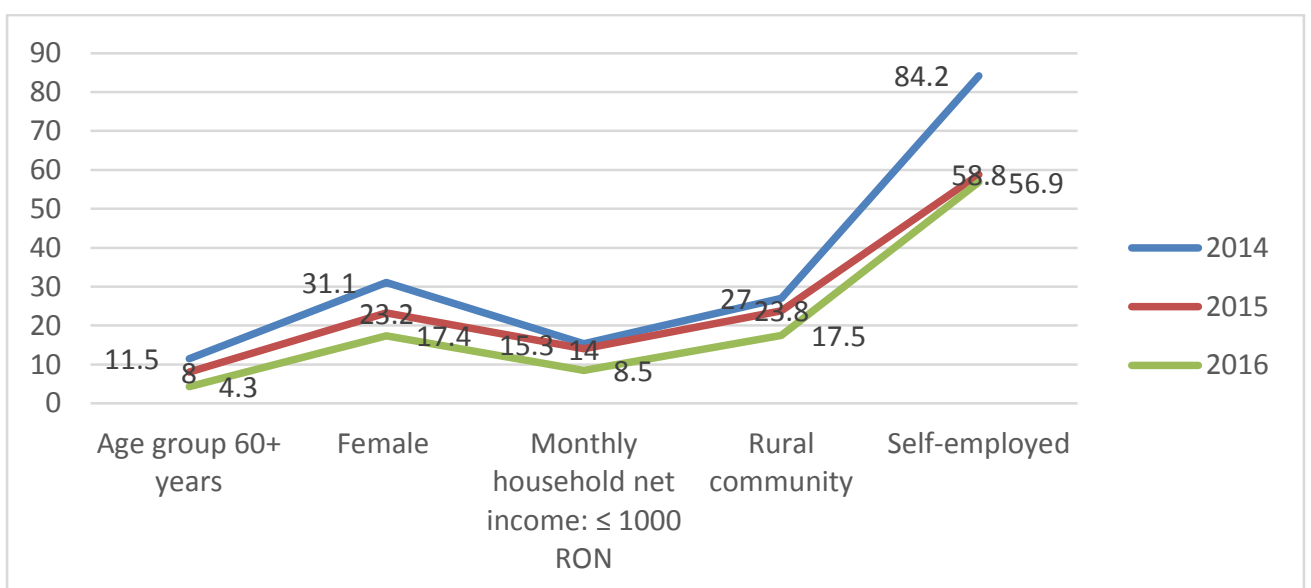

Figure 2. Trend lines of entrepreneurship intention among sample populations (\%)

Source: Authors' own research. Processed based on AGER $2014 \div 2016$ data.

On the other hand, the willingness of self-employed population with a positive attitude towards entrepreneurship to start again a new business remain still high in 2016 (54.9\%), but was visibly decreasing since 2014 (79.4\%). Also, in 2016 a small number of self-employed people with negative attitude towards entrepreneurship will start again a new business (2.0\% in 2016).

\section{Entrepreneurship as desirable career choice}

The desirability for people of age 60+ to consider entrepreneurship as a career opportunity is also low in $2016(10.2 \%)$ as only $13.5 \%$ (2015) of this population perceive the Romanian society as being entrepreneurship friendly (Figure 3). The value of the indicator is decreasing relative to the previous year. Also, more than one third (34.2\%) of this segment of population perceives people in Romania will be more likely to be self-employed in fulltime or part-time than today or as likely as today. Almost on third of the surveyed female population consider entrepreneurship as an appealing career opportunity, and the trend line is slightly decreasing in 2016 relative to the previous year, even if only about $20 \%$ of this population perceive the Romanian society as being entrepreneurship friendly. Also, 
more than half $(53.1 \%)$ of the surveyed female population believe that people in Romania will be more likely to be self-employed in full-time or part-time than today or as likely as today. Furthermore, the desirability of people with a monthly net income of up to 1000 RON to consider entrepreneurship as a career opportunity is very low in $2016(11.8 \%)$, lower than in the previous year as only $15 \%$ (in 2015) of this population perceive the Romanian society as being entrepreneurship friendly. The value of the indicator shows slight decrease relative to the previous year. Although, almost $40 \%$ of this segment of population believe that, in the future, people in Romania will be more likely to be self-employed in full-time or part-time than today or as likely as today. On the other hand, the desirability of people from rural areas to consider entrepreneurship as a career choice is quite high in 2016 (31.1\%), even if only $17 \%$ (in 2015) of this population perceive the Romanian society as being entrepreneurship friendly. The value of this indicator is encouraging, but displays a decreasing trend line relative to the previous year (a decrease of 17.5\%). Also, on five-year time horizon, almost half of the rural people surveyed believe that people in Romania will be more likely to be self-employed in full-time or part-time than today or as likely as today.

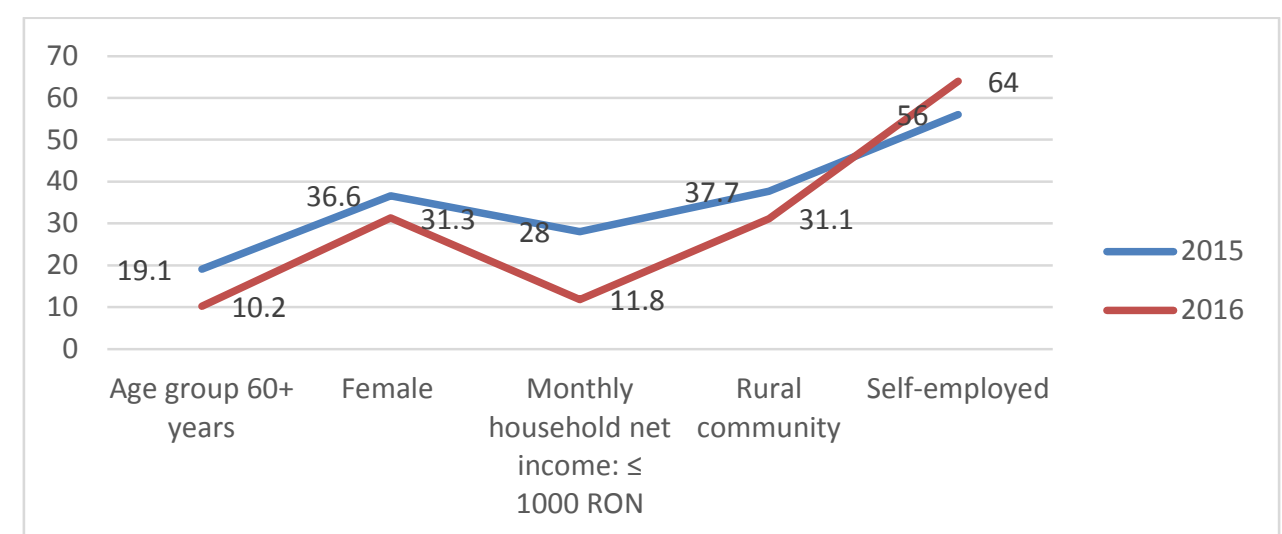

Figure 3. Trend lines of entrepreneurship career appealing among sample populations (\%) Source: Authors' own research. Processed based on AGER 2014 $\div 2016$ data.

The desirability of self-employed population to further embrace entrepreneurship as a career choice remains quite high in 2016 (64.0\% against 56.0\% in 2015), even if only $23.0 \%$ (in 2015) of this population perceive the Romanian society as being entrepreneurship friendly.

A comparison between average weights in attitude, intention and desirability of starting a business between the vulnerable populations studied and self-employed people reveals us interesting results (Table 1). As such, the positive attitude towards entrepreneurship among vulnerable populations, on average, is decreasing from 2014 $(65 \%)$ to $2016(44.8 \%)$ and is lower than the same measure for self-employed population (2014-91\%, $2016-74.1 \%)$. Also, the value decreased below the mean in comparison with the positive attitude displayed by self-employed individuals which increased in 2016.

Table 1. Average weights in attitude, intention and desirability to pursue an entrepreneurship career by population group: vulnerable population groups vs. selfemployed

201420152016

DOI: 10.2478/picbe-2018-0064, pp. 718-727, ISSN 2558-9652| Proceedings of the $12^{\text {th }}$ International Conference on Business Excellence 2018 


\begin{tabular}{lcccccc}
\cline { 2 - 7 } & $\begin{array}{c}\text { Average for } \\
\text { studied pop. } \\
(\%)\end{array}$ & $\begin{array}{c}\text { Self- } \\
\text { employed } \\
(\%)\end{array}$ & $\begin{array}{c}\text { Average for } \\
\text { studied pop. } \\
(\%)\end{array}$ & $\begin{array}{c}\text { Self- } \\
\text { employed } \\
(\%)\end{array}$ & $\begin{array}{c}\text { Average for } \\
\text { studied pop. } \\
(\%)\end{array}$ & $\begin{array}{c}\text { Self- } \\
\text { employed } \\
(\%)\end{array}$ \\
\hline $\begin{array}{l}\text { Positive attitude } \\
\text { towards } \\
\text { entrepreneurship }\end{array}$ & 65.0 & 91.0 & 45.6 & 71.1 & 44.8 & 74.1 \\
\hline $\begin{array}{l}\text { Intention to start a } \\
\text { business }\end{array}$ & 21.2 & 82.2 & 17.2 & 59.8 & 11.9 & 56.9 \\
\hline $\begin{array}{l}\text { Starting a business } \\
\text { as a desirable } \\
\text { career opportunity }\end{array}$ & N/A & N/A & 30.3 & 56 & 21.1 & 64 \\
\hline
\end{tabular}

PICBE $\mid 725$

Source: Authors' own research. Processed based on AGER $2014 \div 2016$ data.

In what regards the perceived intention of starting a business, this is very low and much lower among vulnerable populations studied than for self-employed people. The value decreased continuously from 2014 (21.2\% vs. 82.2\%) to 2016 (11.9\% vs. 56.9\%). However, the trend line also shows a constant decrease for self-employed population. To what concerns desirability to embrace a self-employment career, whilst for vulnerable populations studied we recorded a decreasing trend (2015: 30.3\% vs. 2016: $21.2 \%$ ), selfemployed population displays an increasing trend (2015: 56\% vs. 2016: 64\%).

\section{Conclusion}

The paper presented some key results on entrepreneurship perception among vulnerable populations in Romania: seniors, females, low income people and rural population. It offered insights into perception of various groups of vulnerable populations regarding starting a business and embracing a self-employment career in their communities.

The results of the research indicated that all of our groups of population display a positive attitude towards entrepreneurship, even if the trend line is decreasing. However, the overall interest of the groups of population studied (including self-employed population) regarding predisposition of starting a business is declining. Therefore, a strong focus should be placed on increasing the prevalence and quality of entrepreneurial learning at all education levels, in the training sector and across all sectors.

Some differences can be noticed for population of females and rural communities, which tempt to follow different trend lines than the other groups. A larger number of females and population from rural areas would rather consider entrepreneurship as a good career choice, even those who manifested a negative attitude towards entrepreneurship. On the contrary, a small number of self-employed people with negative attitude towards entrepreneurship will start again a new business. This comes as a result of the general perception that Romanian society is not very entrepreneurship friendly.

All of our research assumptions proved to be confirmed through analysis. The results of the study are useful for policy makers in considering and designing alternative policy interventions meant to nurture entrepreneurship spirit and initiatives among vulnerable populations in Romania. Based on the findings of the paper, a number of implications can be derived particularly for government institutions or policy makers trying to promote entrepreneurial development among vulnerable populations in their respective country. First of all, they need to ensure that this population has the necessary knowledge and skills in place to get (self)-employed. Secondly, government institutions need to create DOI: 10.2478/picbe-2018-0064, pp. 718-727, ISSN 2558-9652| Proceedings of the $12^{\mathrm{t}}$ International Conference on Business 
the right environment that motivates and encourages population to start their own business, not only by providing the right knowledge and training, but also by helping it secure seed funds to start the business. Thirdly, adequate mechanisms should be put in place to facilitate access to expertize and funding for each of the groups of population perceived as being somehow vulnerable.

Our study, like most researches, is not without limitations. The main limitation is given by the limited prior research on this topic which prevented us to add detailed interpretations to our findings. Despite its limitations, the study offers valuable insights to academics, practitioners and government officials who may want to review the effectiveness of current systems of their country and make changes in order to foster the entrepreneurial mindsets among vulnerable individuals.

\section{References}

Anwar, M.U., \& Rashid, A.G. (2011). Female entrepreneurs: A review of the literature and proposed conceptual framework. Proceedings of 2nd International Conference on Business Management. Retrieved from www.umt.edu.pk/ icobm2012/pdf/2C78P.pdf.

Berthe, A., Berthe-Sanou, L., Konate, B., et al. (2013). The elderly in sub-Saharan Africa: a vulnerable population often ignored in public policy. Sante Publique, 25, 367-371.

Botham, R., \& Graves, A. (2009). The grey economy: How third age entrepreneurs are contributing to growth. [Online.] [Research Report.] London: NESTA. [Cit. 15. 2. 2015.] Retrived from http://www.nesta.org.uk/library/documents/third-ageentrepreneurs-report.pdf.

Goh, E.C.L. (2015). Vulnerable families as active agents of their own change process: A bidirectional perspective. Social Work, 60, 145-154.

Goudarzi, S., Ismaili, R., \& Jahanbakhsh, I. (2016). Sociological analysis of professional skills and its impact on the employment of female-headed households (with emphasis on female-headed households covered by the relief committee of Imam Khomeini in Tehran in 2014). Social Sciences, 11, 439-446.

Hukampal, S., \& Bhowmick, B. (2016). Innovation network for entrepreneurship development in rural Indian context: exploratory factor analysis. International Journal of Innovation and Technology Management, 13(4), 1-20.

Kolawole, O.D., \& Ajila, K. (2015). Driving local community transformation through participatory rural entrepreneurship development. World Journal of Entrepreneurship Management and Sustainable Development, 11(2), 131-139.

McGowan, P., Redeker, C.L., Cooper, S.Y., et al. (2012). Female entrepreneurship and the management of business and domestic roles: Motivations, expectations and realities. Entrepreneurship and regional development, 24, 53-72.

OECD (2012), Entrepreneurship at a Glance 2012, OECD Publishing, pp. 110-111, doi: 10.1787/entrepreneur_aag-2012-26-en

Păunescu C, \& Blid L., 2017. Seniorpreneur as a career option for smart active ageing. A study on Romania, Proceedings of the International Conference on Business Excellence, 11 (1), 826-833

Purdue, 0. (2017). Surviving the industrial city: The female poor and the workhouse in late nineteenth-century Belfast. Urban History, 44, 69-90.

DOI: 10.2478/picbe-2018-0064, pp. 718-727, ISSN 2558-9652| Proceedings of the $12^{\text {th }}$ International Conference on Business Excellence 2018 
Salleh, M., \& Sidek, N. (2011). Rural entrepreneurship: a challenges and opportunities of rural micro enterprise (RME) in Malaysia. Interdisciplinary Journal of Contemporary Research in Business, 2(11), 573-585.

Shabunova, A.A., Kalachikova, O.N., Leonidova, G., V, et al. (2016). Exclusion as a Criterion for Selecting Socially vulnerable population Groups. Economic and Social Changes Facts Trends, 44, 22-47.

\section{Appendix 1}

\section{Entrepreneurship perception of sample populations}

\begin{tabular}{|c|c|c|c|c|c|c|c|c|c|c|c|c|c|c|c|}
\hline \multirow{2}{*}{$\begin{array}{c}\text { Population group } \\
\text { Year }\end{array}$} & \multicolumn{3}{|c|}{$\begin{array}{c}\text { Age group 60+ years } \\
\text { n1 (\%) }\end{array}$} & \multicolumn{3}{|c|}{$\begin{array}{l}\text { Female } \\
\mathrm{n} 2(\%)\end{array}$} & \multicolumn{3}{|c|}{$\begin{array}{c}\text { Monthly household net } \\
\text { income: } \leq 1000 \text { RON } \\
\text { n3 (\%) }\end{array}$} & \multicolumn{3}{|c|}{$\begin{array}{c}\text { Rural community } \\
\text { n4 (\%) } \\
\end{array}$} & \multicolumn{3}{|c|}{$\begin{array}{c}\text { Self-employed } \\
\text { n5 (\%) }\end{array}$} \\
\hline & 2016 & 2015 & 2014 & 2016 & 2015 & 2014 & 2016 & 2015 & 2014 & 2016 & 2015 & 2014 & 2016 & 2015 & 2014 \\
\hline $\begin{array}{c}\text { Respondents base } \\
\text { N }(100 \%)\end{array}$ & 271 & 288 & 254 & 531 & 562 & 547 & 145 & 192 & 181 & 471 & 499 & 444 & 33 & 52 & 41 \\
\hline $\begin{array}{l}\text { My attitude towards } \\
\text { entrepreneurship is } \\
\text { positive }\end{array}$ & $\begin{array}{l}103 \\
(38.0)\end{array}$ & $\begin{array}{l}113 \\
(39.3)\end{array}$ & $\begin{array}{l}137 \\
(54.1)\end{array}$ & $\begin{array}{l}269 \\
(50.6)\end{array}$ & $\begin{array}{l}302 \\
(53.8)\end{array}$ & $\begin{array}{l}400 \\
(73.2)\end{array}$ & $\begin{array}{l}58 \\
(38.8)\end{array}$ & $\begin{array}{l}74 \\
(37.5)\end{array}$ & $\begin{array}{l}109 \\
(60.2)\end{array}$ & $\begin{array}{l}244 \\
(51.9)\end{array}$ & $\begin{array}{l}260 \\
(52.1)\end{array}$ & $\begin{array}{l}323 \\
(72.7)\end{array}$ & $\begin{array}{l}25 \\
(74.1)\end{array}$ & $\begin{array}{l}37 \\
(71.1)\end{array}$ & $\begin{array}{l}37 \\
(91.0)\end{array}$ \\
\hline $\begin{array}{r}\ldots \text { and I can imagine } \\
\text { starting my our } \\
\text { business }\end{array}$ & $\begin{array}{r}6 \\
(2.3)\end{array}$ & $\begin{array}{r}20 \\
(7.0)\end{array}$ & $\begin{array}{r}21 \\
(8.4)\end{array}$ & $\begin{array}{r}66 \\
(12.5)\end{array}$ & $\begin{array}{r}117 \\
(20.8)\end{array}$ & $\begin{array}{r}153 \\
(28.0)\end{array}$ & $\begin{array}{r}8 \\
(5.1)\end{array}$ & $\begin{array}{r}22 \\
(10.4)\end{array}$ & $\begin{array}{r}24 \\
(13.1)\end{array}$ & $\begin{array}{r}64 \\
(13.7)\end{array}$ & $\begin{array}{r}105 \\
(21.0)\end{array}$ & $\begin{array}{r}106 \\
(23.9)\end{array}$ & $\begin{array}{r}18 \\
(54.9)\end{array}$ & $\begin{array}{r}28 \\
(54.3)\end{array}$ & $\begin{array}{r}32 \\
(79.4)\end{array}$ \\
\hline $\begin{array}{l}\text { My attitude towards } \\
\text { entrepreneurship is } \\
\text { negative }\end{array}$ & $\begin{array}{l}118 \\
(43.5)\end{array}$ & $\begin{array}{l}111 \\
(38.7)\end{array}$ & $\begin{array}{l}82 \\
(32.2)\end{array}$ & $\begin{array}{l}188 \\
(35.5)\end{array}$ & $\begin{array}{l}175 \\
31.1)\end{array}$ & $\begin{array}{l}107 \\
(19.5)\end{array}$ & $\begin{array}{l}62 \\
(42.7)\end{array}$ & $\begin{array}{l}83 \\
(42.9)\end{array}$ & $\begin{array}{l}44 \\
(24.5)\end{array}$ & $\begin{array}{l}167 \\
(35.5)\end{array}$ & $\begin{array}{l}174 \\
(34.8)\end{array}$ & $\begin{array}{l}82 \\
(18.4)\end{array}$ & $\begin{array}{l}8 \\
(22.7)\end{array}$ & $\begin{array}{l}13 \\
(24.4)\end{array}$ & $\begin{array}{l}3 \\
(6.9)\end{array}$ \\
\hline $\begin{array}{r}. . \text { but however I can } \\
\text { imagine starting my } \\
\text { our business }\end{array}$ & $\begin{array}{r}5 \\
(2.0)\end{array}$ & $\begin{array}{r}3 \\
(1.0)\end{array}$ & $\begin{array}{r}8 \\
(3.1)\end{array}$ & $\begin{array}{r}26 \\
(4.9)\end{array}$ & $\begin{array}{r}13 \\
(2.4)\end{array}$ & $\begin{array}{r}17 \\
(3.1)\end{array}$ & $\begin{array}{r}5 \\
(3.4)\end{array}$ & $\begin{array}{r}4 \\
(3.6)\end{array}$ & $\begin{array}{r}4 \\
(2.2)\end{array}$ & $\begin{array}{r}18 \\
(3.8)\end{array}$ & $\begin{array}{r}14 \\
(2.8)\end{array}$ & $\begin{array}{r}14 \\
(3.1)\end{array}$ & $\begin{array}{r}1 \\
(2.0)\end{array}$ & $\begin{array}{r}2 \\
(4.5)\end{array}$ & $\begin{array}{r}1 \\
(2.8)\end{array}$ \\
\hline $\begin{array}{l}\text { I consider starting a } \\
\text { business as a } \\
\text { desirable career } \\
\text { opportunity for } \\
\text { myself }\end{array}$ & $\begin{array}{l}28 \\
(10.2)\end{array}$ & $\begin{array}{l}55 \\
(19.1)\end{array}$ & $\mathrm{N} / \mathrm{A}$ & $\begin{array}{l}166 \\
(31.3)\end{array}$ & $\begin{array}{l}206 \\
(36.6)\end{array}$ & $\mathrm{N} / \mathrm{A}$ & $\begin{array}{l}19 \\
(11.8)\end{array}$ & $\begin{array}{l}56 \\
(28)\end{array}$ & $\mathrm{N} / \mathrm{A}$ & $\begin{array}{l}146 \\
(31.1)\end{array}$ & $\begin{array}{l}188 \\
(37.7)\end{array}$ & $\mathrm{N} / \mathrm{A}$ & $\begin{array}{l}21 \\
(64.0)\end{array}$ & $\begin{array}{l}29 \\
(56.0)\end{array}$ & N/A \\
\hline
\end{tabular}

Source: Processed based on Self-Employment / AGER 2014, 2015, 2016 - Romania. 